\title{
ANALISIS MODEL INDEKS ZAKAT NASIONAL UNTUK MENILAI KINERJA ZAKAT (Studi Kasus Baznas Kabupaten Solok Sumatera Barat Tahun 2020)
}

\author{
Annisa Maulidia Alfian; Arif Pujiyono; Alfian \\ Universitas Diponegoro Semarang \\ e-mail: annisa.maulidia99@gmail.com; arifpujiyono@ lecturer.undip.ac.id; \\ alfianalfian209@gmail.com
}

\begin{abstract}
This research aims at measuring BAZNAS Solok Regency performance in order to evaluate and improve performance in managing zakat. The potential of Zakat in Solok Regency is very large, but the process of collecting zakat carried out by BAZNAS Solok Regency has not been maximized. This problem is because of the low-level of public trust in distributing zakat to institutions. The public trust will increase if the institution performs the reliable and credible performance. Data collection methods is accomplished through interviews and questionnaires. The analysis method uses the National Zakat Index (NZI) and Instrument Test which includes validity test, reliability test and paired test. The results of the BAZNAS Solok Regency research from the macro dimension are quite good with an index value of 0.50, as there is no APBD support from Solok Regency government and the zakat institution database is not completed yet. From the micro dimension, the performance assessment of BAZNAS Solok Regency is good with an index value of 0.61, as well as the value of institutional indicators including collection, management, delivery and reporting that turns out well. Yet, the impact of the zakat given needs such further reevaluation, because BAZNAS Solok Regency has not carried out guidance, monitoring and evaluation on the material side and spiritual mustahik.
\end{abstract}

Keywords: zakat performance; national zakat index; BAZNAS

\section{Pendahuluan}

Kabupaten Solok merupakan salah satu daerah yang berada di Provinsi Sumatera Barat yang memiliki sumber daya alam yang melimpah, meski demikian, kesejahteraan masyarakat dalam mencukupi kebutuhan hidup belum merata. Saat ini tingkat kemiskinan di Kabupaten Solok pada tahun 2020 mencapai 7.81\%. ${ }^{1}$ Indeks kedalaman kemiskinan Kabupaten Solok yang menunjukkan kesenjangan pengeluaran masing-masing penduduk miskin terhadap garis kemiskinan menduduki peringkat kedua di Sumatera Barat dengan angka $1.16 \%{ }^{2}$ Kemiskinan menurut World Bank didefinisikan sebagai bentuk kehilangan kesejahteraan. Sedangkan masalah inti kemiskinan adalah batasan-batasan tentang kesejahteraan itu sendiri yang terdiri dari banyak dimensi, di antaranya rendahnya tingkat kesehatan dan pendidikan, akses

\footnotetext{
${ }^{1}$ Badan Pusat Statistik, Garis Kemiskinan Menurut Kabupaten/Kota di Sumatera Barat (rupiah/kapita/bulan) 2018-2020 (Padang: Badan Pusat Statistik Sumatera Barat, 2020), 38.

${ }^{2}$ Ibid.
} 
masyarakat misikin terhadap air bersih dan sanitasi, keamanan fisik yang tidak memadai, kurangnya suara dan kapasitas memadai serta kesempatan hidup yang lebih baik. ${ }^{3}$

Zakat merupakan salah satu pilar dalam rukun Islam yang menjadi kewajiban seorang muslim untuk menunaikannya. Zakat dalam pelaksanaanya memiliki dua aspek, yakni aspek ketuhanan (habl min Allah) dan aspek kemanusiaan (habl min al-nass). Terkait aspek ketuhanan (habl min Allah), kewajiban zakat dan kewajiban salat disandingkan sebanyak 27 ayat di dalam al-Quran. ${ }^{4}$ Salah satu manfaat zakat dari sisi pembangunan umat adalah instrumen pemerataan pendapatan. Zakat yang dikelola dengan baik memungkinkan untuk membangun pertumbuhan ekonomi sekaligus pemerataan pendapatan. ${ }^{5}$ Pengelolaan zakat di Indonesia diatur dalam Undang-Undang Republik Indonesia Nomor 23 Tahun 2011, dijelaskan bahwa terdapat dua lembaga pengelola zakat, yakni BAZNAS (Badan Amil Zakat Nasional) dan LAZ (Lembaga Amil Zakat).

Kabupaten Solok memiliki potensi zakat yang sangat besar karena masyarakat Kabupaten Solok mayoritas beragama Islam. Jumlah penduduk Islam di daerah ini mencapai 99,94\%, sedangkan penganut agama Kristen sebesar 0,057\%. ${ }^{6}$ Meskipun memiliki potensi zakat yang besar, jumlah zakat yang dihimpun oleh BAZNAS di Kabupaten Solok belum seutuhnya maksimal. Potensi zakat di Kabupaten Solok sebesar 25 miliar rupiah sedangkan jumlah zakat yang telah dihimpun BAZNAS hanya 6.8 miliar rupiah. ${ }^{7}$

Pengumpulan zakat yang belum maksimal diakibatkan oleh rendahnya kepercayaan masyarakat untuk menyalurkan zakatnya melalui lembaga zakat. Masyarakat lebih memilih untuk menyalurkan zakat secara langsung kepada penerima yang dikenal. Hal itu menjadi salah satu permasalahan dalam dunia perzakatan. Seharusnya lembaga zakat dikelola dengan manajemen yang baik agar masyarakat percaya akan kehadiran lembaga zakat itu sendiri. Selain itu, database mustahiq yang dimiliki oleh BAZNAS belum mencakup seluruh mustahiq. Dari data BAZNAS hanya terdapat 8057 mustahiq yang terhimpun di database BAZNAS. Sedangkan penduduk Kabupaten Solok yang mayoritas beragama Islam memiliki jumlah penduduk miskin sebanyak 29.740 Jiwa. $^{8}$ Data tersebut menunjukkan bahwa zakat belum terdistribusi secara merata kepada mustahiq yang ada di Kabupaten Solok. Pada realisasi zakat yang terkumpul dan tersalurkan oleh BAZNAS memperlihatkan belum optimalnya kegiatan pengelolaan zakat oleh BAZNAS Kabupaten Solok.

Masyarakat akan percaya kepada lembaga zakat jika kinerja dari lembaga zakat itu baik. Menurut penelitian yang dilakukan oleh Noor, ${ }^{9}$ menjelaskan bahwa lembaga pengelolaan zakat harus mampu menunjukkan kemampuan untuk beroperasi pada tingkat optimal dan efisien, karena jika terjadi kegagalan pada suatu lembaga akan menurunkan tingkat

\footnotetext{
3 Bank Indonesia, Pengelolaan Zakat yang Efektif: Konsep dan Praktik di Beberapa Negara (Jakarta: Departemen Ekonomi dan Keuangan Syariah Bank Indonesia, 2016), 94.

${ }^{4}$ M. A. Hasan, Zakat dan Infak (Jakarta: Prenada Media Group, 2006), 76.

${ }^{5}$ D. Hafidhuddin, Zakat dalam Perekonomian Modern (Jakarta: Gema Insani, 2002), 29.

${ }^{6}$ Kementerian Agama RI, "Jumlah Penduduk Menurut Kabupaten/Kota dan Agama yang Dianut", dalam rupawan.kemenag.go.id. Diakses pada 11 Agustus 2020.

7 BAZNAS Kabupaten Solok, "Potensi Zakat Kabupaten Solok" dalam Laporan BAZNAS Kabupaten Solok tahun 2019.

${ }^{8}$ www.bps.go.id diakses pada 12 Agustus 2020.

${ }^{9}$ A. H. Noor, "Assessing Performance of Nonprofit Organization: A Framework for Zakat Institutions," British Journal of Economics, Finance and Management Sciences, Volume 5, Nomor 13 (2012), 52.
} 
kepercayaan masyarakat. Kinerja suatu lembaga zakat yang baik menjadi alasan untuk mempertahankan kepercayaan umat Islam pada lembaga. Mukhlis ${ }^{10}$ dalam penelitiannya mengidentifikasi faktor-faktor yang mempengaruhi kepatuhan membayar zakat. Salah satu faktornya adalah kecakapan organisasi pengelola zakat. Kinerja OPZ yang profesional dapat membuat mustahiq lebih patuh untuk membayar zakat di lembaga tersebut. Meningkatkan mutu pelayanan OPZ seperti dalam hal transparansi, sosialisasi, dan administrasi, maka preferensi responden dalam membayar zakat di lembaga tersebut semakin meningkat. Dalam memastikan kinerja lembaga perlu adanya pengukuran kinerja lembaga zakat.

Kinerja lembaga zakat dapat dievaluasi dengan menggunakan Indeks Zakat Nasional (IZN) yang dibuat oleh Pusat Kajian Strategis BAZNAS. Indeks Zakat Nasional (IZN) merupakan indeks komposit yang dibangun dengan tujuan untuk mengukur perkembangan kondisi perzakatan nasional. IZN dapat menjadi indikator yang dapat memberikan gambaran sejauh mana zakat telah berperan terhadap kesejahteraan mustahiq, dan juga dapat menunjukkan pada tahap apa institusi zakat telah dibangun, baik secara internal kelembagaan, partisipasi masyarakat, maupun dari sisi dukungan yang diberikan pemerintah.

Terdapat beberapa penelitian yang menggunakan IZN sebagai metode analisisnya. Farchatunnisa $^{11}$ dalam penelitiannya yang berjudul Analisis Kinerja BAZNAS Kota Bandung dengan pendekatan Indeks Zakat Nasional menggunakan metode penghitungan yang dinamakan Multi-Stage Weight Index. Hasil dari penelitian ini adalah Kinerja zakat Kota Bandung dari sisi makro memiliki nilai 0.047. Dari sisi mikro, kinerja zakat Kota Bandung cukup baik dengan nilai 0.56. Secara keseluruhan, indikator kelembagaan memiliki nilai indeks 0.5 yang artinya kinerja zakat di Kota bandung dinilai cukup baik. Indikator dampak zakat memiliki nilai indeks 0.6 yang artinya kinerja zakat Kota Bandung terkait dampak zakat terhadap material, spiritual, pendidikan, kesehatan dan kemandirian mustahiq sudah baik.

Selain itu, terdapat penelitian yang dilakukan oleh Putri ${ }^{12}$ yang berjudul Analisis Kinerja Pengelolaan Zakat di Badan Amil Zakat Nasional (BAZNAS) Kota Yogyakarta. Peneliti melakukan pengambilan sampel dilakukan dengan teknik purposive sampling. Hasil dari penelitiannya adalah nilai IZN BAZNAS Kota Yogyakarta adalah 0.4338. Nilai tersebut menunjukkan bahwa kinerja BAZNAS kota Yogyakarta sudah cukup baik. Nilai indeks pada dimensi makro, adalah 0.0495 dengan kategori kinerja tidak baik. Nilai indeks pada dimensi mikro, yaitu 0.69 dan termasuk dalam kategori kinerja baik.

Penelitian yang dilakukan oleh Nadhia ${ }^{13}$ dengan judul Analisis Kinerja BAZIS Kota Jakarta Selatan. Alat analisis yang digunakan dalam penelitian ini adalah Indeks Zakat nasional (IZN) dengan metode dinamakan mixed methods. Hasil dari penelitiannya adalah penilaian dimensi makro adalah cukup baik dengan nilai indeks 0.425 . Hal ini disebabkan adanya anggaran APBD untuk biaya operasional lembaga akan tetapi tidak diimbangi dengan adanya regulasi dari pemerintah. Dari sisi mikro, penilaian kinerja cukup baik. Indikator

\footnotetext{
10 Ahamd Mukhlis, "Analisis Faktor-Faktor yang Mempengaruhi Tingkat Kepatuhan Membayar Zakat: Studi Kasus Kabupaten Bogor,” Al-Muzara'ah, Volume 1, Nomor 1 (2019), 73.

11 H. Farchatunnisa, "Analisis Kinerja Baznas Kota Bandung dengan Pendekatan Indeks Zakat Nasional," Repository IPB (2017).

12 Y. H. Putri, "Analisis Kinerja Pengelolaan Zakat di Badan Amil Zakat Nasional (BAZNAS) Kota Yogyakarta," Repository IPB (2017).

${ }^{13}$ Nadhia Shalehanti, “Analisis Kinerja BAZIS Jakarta Selatan,” Repository IPB (2017).
} 
Kelembagaan memperoleh nilai indeks 0.55 dan dampak zakat 0.55 .

Dari beberapa penelitian yang menilai kinerja Lembaga zakat menggunakan IZN, belum ada satupun penelitian yang menjadikan BAZNAS Kabupaten Solok sebagai objeknya. Tujuan dari penelitian ini adalah untuk menganalisis kinerja BAZNAS Kabupaten Solok menggunakan IZN melalui capaian indikator pada dimensi makro dan makro. Hasil dari analisis akan memberikan gambaran sejauh mana zakat telah berperan terhadap kesejahteraan mustahiq, dan juga dapat menunjukkan pada tahap apa institusi zakat telah dibangun, baik secara internal kelembagaan, partisipasi masyarakat, maupun dari sisi dukungan yang diberikan pemerintah. Hasil tersebut dapat menjadi bahan evaluasi dan pembuatan strategi untuk meningkatkan kinerja BAZNAS Kabupaten Solok.

\section{Definisi Zakat}

Menurut bahasa (etimologi), kata zakat berasal dari bahasa Arab zaka-yazku-zakāanzakātan, mempunyai arti al-namwu wa al-ziyädah, yaitu berkembang, bertambah, berkah, tumbuh, bersih dan baik. ${ }^{14}$ Zakat dalam pengertian berkah ialah sisa harta yang sudah dikeluarkan zakatnya secara kualitatif akan mendapat berkah dan akan berkembang meskipun secara kuantitatif jumlahnya menyusut. ${ }^{15}$

Menurut Undang-Undang Nomor 23 Tahun 2011 Tentang Pengelolaan Zakat, zakat adalah harta benda yang harus dikeluarkan oleh seorang muslim atau badan usaha untuk diberikan kepada yang membutuhkan berdasarkan syariah Islam. Berdasarkan definisi di atas, dapat disimpulkan bahwa zakat merupakan salah satu kewajiban umat Islam dan salah satu rukun Islam. Jika seorang muslim memiliki kekayaan dan mencapai nișab, maka ia harus membelanjakan sebagian hartanya untuk diberikan kepada yang membutuhkan (mustahiq). Zakat adalah cara menyucikan dan membersihkan jiwa dan kekayaan sebagaimana diajarkan Islam seperti yang dinyatakan dalam al-Quran. ${ }^{16}$

Zakat diberikan kepada delapan golongan, sebagaimana yang ada dalam surah alTaubah ayat 60, yaitu orang fakir, orang miskin, amil zakat, yang dilunakkan hatinya (muallaf), untuk (memerdekakan) hamba sahaya, untuk (membebaskan) orang yang berutang, untuk jalan Allah dan untuk orang yang sedang dalam perjalanan sebagai.

Zakat terbagi menjadi dua jenis. Pertama, zakat fitrah yang merupakan zakat yang wajib dikeluarkan menjelang hari raya Idul Fitri oleh setiap muslimin baik tua, muda, ataupun bayi yang baru lahir. Zakat ini biasanya dibentuk sebagai makanan pokok seperti beras. Besaran dari zakat ini adalah 2,5 kilogram atau 3,5 liter beras yang biasanya dikonsumsi. Pembayaran zakat fitrah ini bisa dilakukan dengan membayarkan harga dari makanan pokok daerah tersebut. Zakat ini dikeluarkan sebagai tanda syukur kepada Allah karena telah menyelesaikan ibadah puasa. Selain itu zakat fitrah juga dapat menggembirakan hati para fakir miskin di hari raya Idul Fitri. Zakat fitrah juga dimaksudkan untuk membersihkan dosa yang mungkin ada ketika seseorang melakukan puasa ramadan. Kedua, zakat mal, merupakan bagian dari harta kekayaan seseorang (juga badan hukum) yang wajib dikeluarkan untuk

\footnotetext{
${ }^{14}$ Wahbah al-Zuhayli, Zakat: Kajian Berbagai Mazhab (Jakarta: PT. Remaja Rosdakarya, 2002), 8.

15 A. Atabik, "Peranan Zakat dalam Pengentasan Kemiskinan," ZISWAF, Volume 2, Nomor 2 (Desember 2015), 340.

${ }^{16}$ S. R. Rahman, “Assesment of Zakat Distribution," International Journal of Islamic and Middle Eastern Finance and management: Emerald Insight, Volume 12, Nomor 5 (2019), 747.
} 
golongan tertentu, setelah dimiliki dalam jangka waktu tertentu dan jumlah minimal tertentu. Dalam Undang Undang Nomor 23 Tahun 2011 tentang Pengelolaan Zakat, pada pasal 4 ayat 2 menyebutkan bahwa harta yang dikenai zakat mal berupa emas, perak, uang, hasil pertanian dan perusahaan, hasil pertambangan, hasil peternakan, hasil pendapatan dan jasa, serta rikaz. Di masa Rasulullah, zakat hanya diwajibkan pada lima jenis harta yaitu emas dan perak; barang perniagaan; binatang-binatang yang mencari makan sendiri seperti unta, sapi dan kambing; tanaman dari tumbuh tumbuhan; dan barang logam dan barang-barang simpanan jahiliyah. ${ }^{17}$

Sementara itu, di masa al-Khulafa' al-Rasyidun terdapat beberapa macam harta yang diperlukan oleh kemaslahatan umat supaya diwajibkan zakat. Maka, di masa Umar ibn Khattab difardhukan zakat atas barang yang dikeluarkan dari laut, ambar, mutiara, mirjan dan lain-lain yang menjadi harta sebagaimana diwajibkan zakat atas barang-barang yang dibawa keluar dan didatangkan ke dalam negeri. Para ulama mengklasifikasikan pembagian Zakat menjadi dua, yaitu zakat dibagikan untuk tujuan konsumsi; dan zakat dibagikan untuk investasi. $^{18}$

\section{Pengumpulan Zakat}

Pemerintah berfungsi sebagai koordinator, motivator, regulator, dan fasilitator dalam pengelolaan zakat. Pengumpulan zakat dilakukan oleh Badan Amil Zakat (BAZ) yang dibentuk oleh pemerintah dan Lembaga Amil Zakat (LAZ) yang dibentuk oleh masyarakat dikukuhkan oleh pemerintah. Wilayah operasional BAZ adalah pengumpulan zakat pada instansi pemerintah tingkat pusat, swasta nasional dan perwakilan Republik Indonesia di luar negeri. BAZ di semua tingkatan dapat membentuk Unit Pengumpulan Zakat (UPZ). UPZ tidak bertugas untuk menyalurkan dan mendayagunakan zakat. Pengumpulan zakat dapat dilakukan melalui penyerahan langsung ke BAZ melalui counter, unit pengumpulan zakat, pos, bank, pemotongan gaji dan pembayaran zakat yang dapat mengurangi penghasilan kena pajak. Tata cara pengumpulan, pendistribusian, dan pendayagunaan zakat dengan cara menentukan formulir pemungutan/pemotongan yang sebelumnya disiapkan dan disepakati oleh instansi terkait dalam pengumpulan zakat tersebut BAZ membuka rekening di bank. Rekening zakat dipisahkan dari rekening infak dan sedekah. ${ }^{19}$

\section{Pengelolaan Zakat}

Indonesia memiliki regulasi tentang pengelolaan zakat. Sesuai dengan Undang-Undang Nomor 23 tahun 2011 tentang Pengelolaan Zakat, dibentuk BAZNAS dari tingkat pusat sampai timgkat kabupaten/kota. BAZNAS merupakan lembaga pemerintah non struktural yang bersifat mandiri dan bertanggung jawab kepada presiden melalui menteri. BAZNAS merupakan lembaga yang berwenang melakukan tugas pengelolaan zakat secara nasional. Untuk membantu BAZNAS dalam pelaksanaan pengumpulan, pendistribusian, dan pendayagunaan zakat, masyarakat dapat membentuk Lembaga Amil Zakat (LAZ).

\footnotetext{
${ }^{17}$ Muhammad ibn Shalih, Fatwa-Fatwa Zakat (Jakarta: Darus Sunnah Press, 2008), 25.

18 H. Ahmed, "Zakah, Macroeconomic Policies, and Poverty Alleviation: Lessons from Simulations on Bangladesh," Journal of Islamic Economics, Banking and Finance, Volume 4, Nomor 2 (2008), 81-105.

19 Direktorat Pemberdayaan Zakat Depag RI, Pedoman Pengelolaan Zakat (Jakarta: Direktorat Bimbingan Masyarakat Islam, 2007), 83.
} 
Pembentukan LAZ wajib mendapat izin menteri atau pejabat yang ditunjuk oleh menteri. LAZ wajib melaporkan secara berkala kepada BAZNAS atas pelaksanaan pengumpulan, pendistribusian, dan pendayagunaan zakat yang telah diaudit syariat dan keuangan.

Tujuan pengelolaan zakat adalah meningkatkan pelayanan pengelolaan zakat yang efektif dan efisien serta pemanfaatan zakat dalam upaya pengentasan kemiskinan dan peningkatan kesejahteraan. Pengelolaan zakat ditangani oleh BAZNAS yang dikoordinasi pemerintah dan Lembaga Amil Zakat yang diprakarsai pengelolaannya secara swadaya masyarakat.

\section{Metode Penelitian}

Dalam penelitian ini digunakan dua metode pengambilan data, yaitu data primer dan data sekunder. Data primer diperoleh dengan cara in-depth interview atau disebut juga wawancara secara mendalam. Wawancara dilakukan untuk mendapatkan informasi yang detail mengenai objek yang sedang diteliti. Wawancara dilakukan terhadap key person dari persoalan yang sedang dibahas, dan dalam hal ini adalah ketua BAZNAS Kabupaten Solok dan wakil ketua bidang penghimpunan dan penyaluran

Selain menggunakan in-depth interview, pengambilan data juga dilakukan melalui kuesioner. Kuesioner merupakan teknik pengumpulan data yang dilakukan dengan cara memberi seperangkat pertanyaan atau pernyataan tertulis kepada responden untuk dijawab. ${ }^{20}$ Kuesioner dalam penelitian ini ditujukan kepada mustahiq sebagai penerima zakat untuk menilai variabel dampak zakat. Sedangkan data sekunder diperoleh melalui data-data dan dokumen-dokumen yang sudah ada di BAZNAS Kabupaten Solok, Badan Pusat Statistik dan literatur-literatur lainnya seperti al-Quran, buku, jurnal, skripsi, website resmi, dan internet. Metode pengumpulan data yang digunakan dalam penelitian ini adalah wawancara dan studi dokumentasi. Wawancara dilakukan terhadap pengurus BAZNAS Kabupaten Solok dan mustahiq. Studi dokumentasi dilakukan dengan cara mengumpulkan data dari instansi yang diteliti.

Metode analisis penelitian ini menggunakan Indeks Zakat Nasional (IZN) dengan memberikan skor pada setiap variabel dalam rentang 0.00-1.00 sesuai dengan data dan kondisi kinerja yang diperoleh. Selain itu, penelitian ini menggunakan skala likert sebagai salah satu skala pengukuran. Skala likert ini digunakan dalam menghitung skor material dan spiritual rumah tangga pada masing-masing variabel indikator kebutuhan material dan spiritual. Uji reliabilitas uji konsistensi responden dalam menjawab pertanyaan kuesioner dan uji paired t test dilakukan untuk melihat perubahan yang terjadi pada peningkatan indeks material dan indeks spiritual rumah tangga sebelum mendapatkan zakat dan sesudahnya. Apakah dengan memberikan zakat oleh BAZNAS Kabupaten Solok berdampak positif pada pengurangan kemiskinan berdasarkan garis kemiskinan Kabupaten Solok dan kemiskinan spiritual berdasarkan model CIBEST atau tidak. Alat ukur kinerja yang digunakan dalam penelitian ini menggunakan IZN yang dibentuk oleh Pusat Kajian Strategis Badan Amil Zakat Nasional (PUSKAS BAZNAS) yang dikeluarkan pada tahun 2016.

\section{Indeks Zakat Nasional (IZN)}

${ }^{20}$ Sugiyono, Metode Penelitian Kuantitatif, Kualitatif dan R\&D (Bandung: Alfabeta, 2013), 47. 
Indeks Zakat Nasional (IZN) merupakan suatu alat ukur yang dapat mengevaluasi perkembangan kondisi perzakatan pada tingkat nasional hingga daerah. Dalam IZN terdapat dua dimensi, yaitu dimensi makro dan mikro. Pada dimensi makro terdapat indicator, yaitu regulasi, dukungan APBN, serta database lembaga zakat. Kecuali indikator regulasi, serta dukungan APBN yang tidak diturunkan kembali menjadi variable, namun untuk indikator database lembaga zakat diturunkan lagi menjadi variabel, yaitu database jumlah lembaga zakat resmi (muzakki dan mustahiq), rasio muzakki individu, rasio muzakki badan usaha.

Pada dimensi mikro terdapat indikator kelembagaan dan dampak zakat. Pada indikator kelembagaan diturunkan lagi menjadi variabel, diantaranya yaitu penghimpunan, pengelolaan, penyaluran, dan pelaporan. Sedangkan untuk indikator dampak zakat diturunkan menjadi variabel kesejahteraan material dan spiritual (indeks kesejahteraan CIBEST), indeks pembangunan manusia islami (IHDI), dan kemandirian. Pada setiap dimensi, indikator serta variabel terdapat bobot yang berbeda sehingga dapat dihitung dengan model estimasi perhitungan yang sudah ada. Dengan adanya IZN diharapkan dapat mengetahui kinerja dari lembaga zakat itu sendiri apakah sudah pada tahap yang telah ditentukan oleh IZN. ${ }^{21}$

\section{Regulasi Zakat}

Untuk mendukung pengelolaan zakat yang berkelanjutan, diperlukan tata kelola yang baik, landasan hukum yang kuat, dan manajemen yang profesional. Dasar hukum yang jelas menjadi fundamental pengembangan zakat di setiap negara. Kepastian hukum menjadi penting untuk memastikan bahwa tidak terdapat pelanggaran penyalahgunaan wewenang dalam pengelolaan zakat di suatu wilayah. ${ }^{22}$ Zakat core principles ${ }^{23}$ pada prinsip pertama, bahwa hukum, regulasi, atau kerangka hukum lainnya untuk supervisi zakat sangat jelas diperlukan untuk membekali setiap otoritas atau pihak yang berwenang dengan kekuatan hukum dan aturan independen dibutuhkan.

\section{Anggaran Pemerintah untuk Zakat}

Sebagaimana tertuang dalam Undang-Undang Nomor 23 tahun 2011 pasal 30 dan 31, bahwa pelaksanaan tugas, fungsi, dan pelayanan BAZNAS pusat, BAZNAS provinsi dan BAZNAS kabupaten/kota dibiayai dengan APBN dan APBD. Lebih jelasnya lagi, sumber pembiayaan tertuang dalam Peraturan Pemerintah Nomor 14 Tahun 2014 pasal 67 dan 69. Dengan demikian, diperlukan koordinasi antar instansi terkait dalam hal pengalokasian APBN dan APBD untuk operasional BAZNAS pusat, BAZNAS provinsi, dan BAZNAS kabupaten/kota. ${ }^{24}$

Terdapat kajian seperti yang dilakukan Daulah ${ }^{25}$ membuktikan kontribusi positif peran peraturan pemerintah anggaran pemerintah nasional dan daerah terhadap zakat. Dari studi di daerah Mojokerto, ditemukan bahwa APBD Kota Mojokerto sangat membantu operasional BAZ Mojokerto, sehingga dana zakat dapat difokuskan untuk kegiatan pengumpulan dan

\footnotetext{
${ }^{21}$ Badan Amil Zakat Nasional, Indeks Zakat Nasional 2.0 (Jakarta: Pusat Kajian Strategis BAZNAS, 2020), 28.

${ }^{22}$ Ibid

${ }^{23}$ Badan Amil Zakat Nasional, Zakat Core Principles (Jakarta: Badan Amil Zakat Nasional, 2016), 36.

${ }^{24}$ Badan Amil Zakat Nasional. Indeks Zakat Nasional 2.0, 51.

${ }^{25}$ M. A. Daulah, "Efektifitas Pengelolaan Perda Pengelolaan Zakat di Kota Mojokerto dan Kabupaten Sidoarjo," Jurnal Hukum dan Perundangan Islam, Volume 3, Nomor 2 (2015), 312.
} 
peningkatan jumlah muzakki serta penyaluran kepada mustahiq zakat.

\section{Database Lembaga Zakat}

Zakat Core Principles (ZCP) juga memuat prinsip mengenai hal-hal yang diizinkan aktivitas pengelolaan baik pengumpulan maupun penyaluran zakat. Salah satu hal untuk mendukung aktivitas pengelolaan zakat adalah adanya database organisasi pengelola zakat yang mudah diakses oleh publik sehingga mempermudah muzakki untuk menunaikan zakatnya. Efektivitas pengumpulan dana zakat dan pendayagunaannya sangat tergantung pada kelengkapan database yang dimiliki, khususnya terkait dengan jumlah muzakki dan mustahiq. ${ }^{26}$

\section{Kelembagaan}

Dalam hal kelembagaan, tata kelola yang baik menjadi isu yang sangat penting karena berhubungan dengan kepercayaan dari stakeholders. Tata kelola ini ikut diatur dalam Zakat Core Principles (ZCP) pada bab ke-8 mengenai good amil governance yang menjamin pengelolaan zakat yang baik melalui kepatuhan syariah, manajemen zakat, lingkungan, perangkat strategis organisasi, dan tanggung jawab dewan dari organisasi pengelola zakat. Sebagai lembaga intermediasi, organisasi pengelola zakat berperan sebagai perantara dari muzakki dan mustahiq. Aspek kelembagaan yang mencakup komponen pengumpulan, pengelolaan, penyaluran dan pelaporan juga tercantum dalam ZCP pada bab ke-9 dan 10 .

Manajemen pengumpulan pada bab-9 ZCP banyak mengulas mengenai kebijakan yang harus dimiliki OPZ terkait asesmen niṣab dan objek zakat untuk memaksimalkan potensi zakat. Adapun manajemen penyaluran zakat pada bab-10 ZCP memberikan pedoman mengenai prinsip kebijakan pendistribusian dan pendayagunaan zakat yang tepat guna. Selain itu, dari segi pelaporan, laporan keuangan badan/lembaga zakat harus diaudit oleh kantor akuntan publik resmi dengan merujuk pada standar penilaian Badan Pemeriksa Keuangan $(\mathrm{BPK}){ }^{27}$

\section{Dampak Zakat}

Dalam dimensi mustahiq, Indeks Zakat Nasional (IZN) 2.0 mengukur dampak zakat terhadap mustahiq yang dapat dinilai dari aspek material, spiritual, kesehatan, pendidikan, dan kemandirian. Pada tahap ini, IZN menggunakan beberapa metode penghitungan yang dibuat oleh institusi lokal maupun internasional. Seperti dalam mengukur dampak zakat secara materi dan spiritual, IZN menggunakan metode CIBEST IPB yang dikembangkan oleh Beik dan Arsyianti.

Pengukuran dampak selanjutnya adalah dengan melihat dari peningkatan standar kelayakan hidup lain melalui indeks pembangunan manusia islami. Selain itu juga dilihat melalui indeks kemandirian yang mengukur kemandirian penerima zakat dalam memiliki pekerjaan. Sebagai sebuah legitimasi syariah, selain sebagai ibadah individual, zakat merupakan ibadah yang memiliki dampak sosial. Zakat diyakini mampu berkontribusi dalam membentuk spirit kebersamaan antara golongan kaya dan miskin. Sebuah masyarakat beradab

${ }^{26}$ Ibid.
${ }^{27}$ Ibid. 
yang golongan kaya tidak sombong karena kekayaannya, dan golongan miskin tidak merasa hina karena kefakirannya.

\section{Indeks CIBEST}

Dampak zakat sebagai salah satu peubah dalam IZN diukur dengan menggunakan indeks kemiskinan islami, yaitu model CIBEST yang dikembangkan oleh Irfan Syauqi Beik dan Laily Dwi Arsyianti. Kuadran CIBEST Model tersusun dari empat indeks, yaitu indeks kesejahteraan, indeks kemiskinan material, indeks kemiskinan spiritual dan indeks kemiskinan absolut. Pengukuran dilakukan dengan unit analisis rumah tangga dan membaginya menjadi enam sub kelompok, yaitu kepala keluarga (KK), orang dewasa bekerja, orang dewasa tidak bekerja (>18 tahun), remaja (14-18 tahun), anak-anak (7-13 tahun) dan anak-anak (hingga usia 6 tahun). Untuk mengetahui tingkat kemiskinan rumah tangga, CIBEST membagi keluarga menjadi empat kategori.

Keluarga yang ada di kuadran pertama dikategorikan sebagai keluarga sejahtera. Hal ini berarti bahwa keluarga tersebut sudah dapat memenuhi kebutuhan material dan spiritual. Keluarga yang ada di kuadran kedua dikategorikan sebagai keluarga miskin material. Pada kuadran ini, keluarga tersebut telah dapat memenuhi kebutuhan spiritualnya dengan baik. Hanya saja mereka masih belum dapat memenuhi kebutuhan materialnya dengan baik. Keluarga yang ada di kuadran ketiga dikategorikan sebagai keluarga miskin spiritual. Keluarga ini telah memenuhi kebutuhan materialnya dengan baik namun dari sisi kebutuhan spiritual belum terpenuhi. Keluarga yang ada di kuadran keempat dikategorikan sebagai keluarga miskin absolut. Artinya, keluarga yang ada di kuadran ini berada di titik kemiskinan terendah karena mereka tidak dapat memenuhi kebutuhan spiritual maupun materialnya.

Penentuan kuadran sebuah keluarga dilakukan dengan menghitung aspek kemiskinan material dan spiritual terlebih dahulu. Aspek kemiskinan material atau material value (MV) diukur dengan tiga pendekatan, yaitu survei periodik tentang kebutuhan dasar material, standar garis kemiskinan menurut BPS, dan batas harta kena zakat (nișab). Pada Penelitian ini metode yang digunakan adalah dengan menggunakan garis kemiskinan Kabupaten Solok yang dikalikan dengan jumlah anggota keluarga yang diteliti. Garis kemiskinan yang digunakan pada penelitian ini merupakan data tahun 2020, yaitu sebesar Rp. 451.906. ${ }^{28}$ Nilai MV dapat dirumuskan sebagai berikut:

$$
\text { MV = garis kemiskinan Kabupaten Solok x jumlah anggota keluarga }
$$

Pada aspek spiritual, model CIBEST mengukur setiap keluarga berdasarkan lima variabel, yaitu salat, puasa, zakat dan infak, lingkungan keluarga dan kebijakan pemerintah. Skala likert dari 1-5 digunakan untuk mengukur kelima variabel pada kebutuhan spiritual.

\section{Indeks Pembangunan Manusia Islami}

Indeks pembangunan manusia islami (IHDI) adalah alat ukur untuk menilai kualitas SDM atau juga kesejahteraan di suatu negara atau daerah dengan memakai pendekatan

\footnotetext{
${ }^{28}$ www.bps.go.id diakses pada 12 Agustus 2020.
} 
maqāsid al-sharīah yang terdiri dari lima dimensi yang dibagi kepada dua ukuran capaian, yaitu kesejahteraan materi dan kesejahteraan non material. Dengan adanya pengukuran pembangunan manusia islami (IHDI) yang lebih holistis mencakup semua aspek kebutuhan manusia yang berlandaskan maqāsid al-sharï'ah diharapkan dapat memberi sumbangan bagi pengembangan konsep yang lebih menyeluruh terhadap pola-pola pembangunan yang akan dilakukan khususnya negara-negara berpenduduk mayoritas muslim. IHDI membagi kebutuhan akan kesejahteraan manusia pada dua bagian, yaitu kesejahteraan material (material walfare) dan kesejahteraan non material (non material walfare). ${ }^{29}$

Pengukuran kemandirian mustahiq rumah tangga dilakukan dengan melihat apakah mustahiq rumah tangga memiliki pekerjaan tetap, usaha/bisnis dan tabungan. Skala likert digunakan untuk mengukur kondisi kemandirian dari para mustahiq rumah tangga.

\section{Profil BAZNAS Kabupaten Solok}

BAZNAS Kabupaten Solok merupakah salah satu lembaga non struktural yang dibentuk pemerintah dari masyarakat untuk masyarakat guna menciptakan kesejahteraan, keadilan dan kedamaian. BAZNAS Kabupaten Solok berada di Komplek Islamic Center Koto Baru Kecamatan Kubung, Kabupaten Solok. Zakat diharapkan mampu mengurangi kesenjangan sosial, kebangkitan ekonomi kerakyatan, terobosan dalam mengurangi kemiskinan, dan pengembangan sumber pendanaan pembangunan di Kabupaten Solok di luar APBD Kabupaten Solok melalui pengelolaan BAZNAS Kabupaten Solok. BAZNAS Kabupaten Solok bertugas untuk melakukan pengumpulan, pendistribusian, dan pendayagunaan dana zakat dan bertanggung jawab kepada pemerintah Kabupaten Solok serta BAZNAS Sumatera Barat.

\section{Analisis Kinerja Pengelolaan Zakat di Kabupaten Solok Berdasarkan Dimensi Makro}

Indeks Zakat Nasional terbagi atas dua dimensi, yaitu dimensi makro dan dimensi mikro. Dimensi makro (X1) memiliki tiga indicator, yaitu regulasi (X11), dukungan APBD (X12), dan database lembaga zakat (X13). Indikator database lembaga zakat memiliki tiga variabel turunan, yaitu lembaga zakat resmi, muzakki dan mustahiq (X131), rasio muzakki individu (X132), dan rasio muzakki badan usaha (X133).

Regulasi

BAZNAS Kabupaten Solok memiliki peraturan daerah mengenai pengelolaan zakat, hal tersebut tertulis pada Peraturan Daerah Nomor 13 Tahun 2015 tentang Pengelolaan Zakat. Kondisi aktual mengenai regulasi BAZNAS Kabupaten Solok tergambar pada Tabel berikut:

Tabel 1.1. Indikator Regulasi

\begin{tabular}{|c|l|l|c|c|c|}
\hline No & Variabel & \multicolumn{1}{|c|}{ Kondisi Aktual } & Skor & Indeks & Penilaian \\
\hline 1 & Regulasi & $\begin{array}{l}\text { Terdapat Perda mengenai } \\
\text { zakat }\end{array}$ & 5 & 1.00 & Sangat Baik \\
\hline
\end{tabular}

29 A. N. Rukiah, "Islamic Human Development Index di Indonesia (Suatu Pendekatan Maqhasid Syariah)," Istinbath, Volume 4, Nomor 2 (2019), 315. 


\section{Dukungan APBD}

BAZNAS Kabupaten Solok tidak mendapatkan dukungan APBD oleh pemerintah Kabupaten Solok. Kondisi aktual dukungan APBD untuk lembaga BAZNAS Kabupaten Solok tergambar pada tabel berikut:

Tabel 1.2. Indikator Dukungan APBD

\begin{tabular}{|c|c|c|c|c|c|}
\hline No & Variabel & Kondisi Aktual & Skor & Indeks & Penilaian \\
\hline 1 & $\begin{array}{l}\text { Dukungan } \\
\text { APBD }\end{array}$ & $\begin{array}{lr}\text { Tidak } & \text { terdapat } \\
\text { dukungan } & \text { APBD } \\
\text { untuk pengelolaan } \\
\text { zakat }\end{array}$ & 0 & 0.00 & Sangat Buruk \\
\hline
\end{tabular}

\section{Database Lembaga Zakat}

Indikator database lembaga zakat terdiri dari tiga variabel. Variabel pertama yaitu jumlah lembaga zakat resmi, muzakki, dan mustahiq menggambarkan kemampuan lembaga dalam mengatur database yang dimiliki serta kelengkapan dari data muzakki dan mustahiq. Variabel kedua yaitu rasio jumlah muzakki individu terhadap jumlah rumah tangga daerah. Variabel ini menggambarkan berapa banyak muzakki individu yang telah membayarkan zakatnya melalui lembaga dengan dibandingkan seluruh rumah tangga yang ada di daerah. Variabel terakhir yaitu rasio muzakki badan terhadap jumlah badan usaha menggambarkan seberapa banyak badan usaha yang membayar zakat perusahaan melalui lembaga zakat. Kondisi aktual database lembaga zakat untuk lembaga BAZNAS Kabupaten Solok tergambar pada tabel berikut:

Tabel 1.3. Indikator Database

\begin{tabular}{|c|l|l|c|c|c|}
\hline No & \multicolumn{1}{|c|}{ Variabel } & \multicolumn{1}{|c|}{ Kondisi Aktual } & Skor & Indeks & Penilaian \\
\hline 1 & $\begin{array}{l}\text { Jumlah lembaga } \\
\text { zakat resmi, } \\
\text { muzakki dan } \\
\text { mustahiq. }\end{array}$ & $\begin{array}{l}\text { Terdapat database jumlah muzakki } \\
\text { dan mustahiq per lembaga. }\end{array}$ & 3 & 0,50 & Cukup Baik \\
2 & $\begin{array}{l}\text { Rasio jumlah } \\
\text { muzakki individu } \\
\text { terhadap jumlah } \\
\text { rumah tangga } \\
\text { daerah. }\end{array}$ & $\begin{array}{l}\text { Rasio Jumlah muzakki terdaftar } \\
\text { yang memiliki NPWZ terhadap } \\
\text { rumah tangga muslim daerah } \\
\text { adalah 1,44\%. }\end{array}$ & 2 & 0,25 & Kurang Baik \\
3 & $\begin{array}{l}\text { Rasio muzakki } \\
\text { badan terhadap } \\
\text { jumlah badan } \\
\text { usaha. }\end{array}$ & $\begin{array}{l}\text { Rasio jumlah muzakki badan } \\
\text { terdaftar yang memiliki NPWZ } \\
\text { terhadap jumlah badan usaha } \\
\text { adalah 0,72\%. }\end{array}$ & 1 & 0,00 & Tidak Baik \\
\hline
\end{tabular}

Berdasarkan tabel di atas, jumlah lembaga zakat resmi, muzakki dan mustahiq mendapatkan skor 3 karena terdapat data lembaga zakat resmi, muzakki dan mustahiq namun tidak terdapat data penyebarannya. Rasio jumlah muzakki individu terhadap jumlah rumah tangga daerah mendapatkan skor 2 atau kurang baik, karena rasio jumlah muzakki individu 
terhadap jumlah rumah tangga daerah hanya 1,44\%. Rasio muzakki badan terhadap jumlah badan usaha mendapatkan skor 1 atau tidak baik, dikarenakan rasio tersebut hanya 0,72\% yang artinya $>1 \%$. Dalam mendapatkan nilai indeks indikator database lembaga zakat menggunakan rumus IZN tahap 3. Maka didapatkan nilai indeks pada dimensi makro sebesar 0.5. Nilai ini termasuk dalam kategori cukup baik, yaitu pada rentang 0.41-0.60. Nilai indeks dimensi makro didapatkan dari hasil penghitungan pada variabel dan indikator pada dimensi makro.

\section{Analisis Kinerja Pengelolaan Zakat di Kabupaten Solok Berdasarkan Dimensi Mikro}

Dimensi mikro pada Indeks Zakat Nasional terdiri dari dua indicator, yaitu kelembagaan (X21) dan dampak zakat (X22). Indikator kelembagaan memiliki empat variabel turunan, yaitu penghimpunan (X211), pengelolaan (X212), penyaluran (X213), pelaporan (X214). Sedangkan indikator lembaga zakat memiliki tiga variabel turunan, yaitu indeks kesejahteraan CIBEST (X221), IHDI (X222), dan kemandirian (X223).

\section{Kelembagaan}

Indikator kelembagaan pada Indeks Zakat Nasional menggambarkan kinerja lembaga pengelola zakat dalam menghimpun, mengelola, menyalurkan dana zakat serta pembuatan laporan secara berkala. Pada variabel penghimpunan menunjukkan seberapa besar peningkatan dana zakat yang mampu dihimpun oleh lembaga. Variabel kedua, yaitu pengelolaan menunjukkan kinerja lembaga dalam hal pengelolaan yang dapat dilihat dari SOP pengelolaan zakat, rencana strategis, program kerja tahunan serta sertifikasi ISO. Variabel ketiga, yaitu penyaluran yang menggambarkan waktu penyaluran dana zakat kepada mustahiq serta alokasi dana untuk program dakwah. Variabel terakhir yaitu pelaporan menggambarkan bahwa lembaga memiliki laporan keuangan yang diaudit dan dipublikasikan secara berkala. Kondisi aktual kelembagaan pada lembaga BAZNAS Kabupaten Solok tergambar pada tabel berikut:

Tabel 1.4. Indikator Kelembagaan

\begin{tabular}{|c|c|c|c|c|c|}
\hline $\mathrm{No}$ & Variabel & Kondisi Aktual & Skor & Indeks & Penilaian \\
\hline 1 & Penghimpunan & $\begin{array}{l}\text { Pertumbuhan (YoY) }>20 \% \\
\text { Besaran pengumpulan } 8,7 \mathrm{M}\end{array}$ & $\begin{array}{l}5 \\
3\end{array}$ & 0,75 & Baik \\
\hline 2 & Pengelolaan & $\begin{array}{l}\text { Memiliki SOP pengelolaan zakat, } \\
\text { dan program kerja tahunan }\end{array}$ & 3 & 0,50 & Cukup baik \\
\hline 3 & Penyaluran & $\begin{array}{l}\text { Besaran Penyaluran } 8,7 \mathrm{M} \\
\text { ACR }>90 \% \\
\text { Program sosial } 9-12 \text { bulan } \\
\text { Program ekonomi } 12 \text { bulan } \\
\text { Program dakwah }>10 \%\end{array}$ & $\begin{array}{l}4 \\
5 \\
3 \\
3 \\
5\end{array}$ & 0,75 & Baik \\
\hline 4 & Pelaporan & $\begin{array}{l}\text { Memiliki laporan keuangan } \\
\text { teraudit WTP, laporan keuangan } \\
\text { syariah }\end{array}$ & 4 & 0,75 & Baik \\
\hline
\end{tabular}


Indikator kelembagaan terdiri dari empat variabel, yaitu penghimpunan, pengelolaan, penyaluran, dan pelaporan. Variabel pertama, yaitu penghimpunan yang terdiri dari pertumbuhan dan besaran pengumpulan zakat mendapatkan nilai indeks 0.75 yang artinya penghimpunan zakat adalah baik. Variabel kedua, yaitu pengelolaan mendapatkan nilai indeks 0,50 yang artinya BAZNAS Kabupaten Solok memiliki SOP penghimpunan dan penyaluran, dan program kerja tahunan tetapi belum memiliki ISO/manajemen mutu sehingga mendapatkan nilai indeks 0.50 yang artinya kinerja dalam pengelolaan cukup baik. Variabel ketiga, yaitu penyaluran mendapatkan skor 0,75 yang artinya penyaluran BAZNAS Kabupaten Solok sebesar 8,7 Milyar dan berada pada rentang 5-15 Milyar, sehingga medapatkan skor 4 dan nilai indeks 0,75. Selain itu, ACR (allocation to collection ratio) BAZNAS Kabupaten Solok lebih dari 90\%, yakni 100\% dan mendapatkan skor 5 dan nilai indeks 1,00. Penyaluran zakat konsumtif dan zakat produktif sekali hingga dua kali dalam 12 bulan, sehingga masing-masing mendapatkan skor 3 dan nilai indeks 0,50. Alokasi dana untuk program dakwah, yaitu 35,7 persen sehingga mendapatkan skor 4 dan nilai indeks 0,75. Setelah diakumulasikan dan dihitung menggunakan rumus IZN, dapat disimpulkan nilai indeks penyaluran sebesar 0,75, artinya penyaluran yang dilakukan cukup baik. Variabel keempat, yakni pelaporan mendapatkan skor 4, artinya BAZNAS Kabupaten Solok memiliki laporan keuangan syariah, laporan keuangan mendapatkan opini audit wajar tanpa pengecualian, sehingga mendapatkan nilai indeks 0,75 yang artinya pelaporan yang dilakukan BAZNAS Kabupaten Solok baik.

\section{Dampak Zakat}

Indikator dampak zakat merupakan penilaian terhadap dampak zakat menggunakan indeks CIBEST yang menilai dampak zakat secara ekonomi dan spiritual, indeks pembangunan manusia islami (IHDI) yang menilai dampak zakat dari lima aspek maqașid alshari' $a h$, yaitu memelihara agama, memelihara jiwa, memelihara akal, memelihara keturunan, memelihara harta dan indeks kemandirian yang melihat sejauh mana produktivitas keluarga mustahiq.

Tabel 1.5. Indikator Dampak Zakat

\begin{tabular}{|c|l|l|c|c|c|}
\hline No & \multicolumn{1}{|c|}{ Variabel } & \multicolumn{1}{|c|}{ Kondisi Aktual } & Skor & Indeks & Penilaian \\
\hline 1 & CIBEST & $\begin{array}{l}\text { Hasil perhitungan menunjukkan } \\
\text { bahwa nilai Indeks CIBEST } \\
0,47\end{array}$ & 3 & 0,50 & Cukup baik \\
\hline 2 & IHDI & $\begin{array}{l}\text { Indeks Pembangunan Manusia } \\
\text { Islami adalah 0,53 }\end{array}$ & 3 & 0.50 & Baik \\
\hline 3 & Kemandirian & $\begin{array}{l}\text { Memiliki salah satu pekerjaan } \\
\text { tetap/bisnis }\end{array}$ & 3 & 0.50 & Cukup baik \\
\hline
\end{tabular}

Dari hasil perhitungan di atas, nilai skor kesejahteraan CIBEST (W) adalah 3 dengan nilai indeks kesejahteraan CIBEST adalah 0.47, yakni pada rentang 0.41-0.60 yang artinya cukup baik. Indikator indeks kesejahteraan CIBEST menggambarkan dampak zakat terhadap tingkat pendapatan dan spiritual mustahiq. Terdapat 4 kuadran pada model CIBEST. Kuadran pertama menggambarkan mustahiq yang kaya material dan spiritual. Kuadran kedua 
menggambarkan kondisi mustahiq yang miskin secara material tetapi kaya secara spiritual. Kuadran ketiga menggambarkan kondisi mustahiq yang kaya secara material tetapi miskin spiritual. Kuadran keempat menggambarkan kondisi mustahiq yang secara material maupun spiritual miskin atau disebut dengan miskin absolut.

Perhitungan IHDI berasal dari indikator-indikator yang dapat mewakili kelima kebutuhan akan tercapainya tujuan maqāsid al-sharíah, maka data-data yang diperoleh berupa data kuantitatif yang diolah menggunakan rumus perhitungan IHDI. Hasil perhitungan menunjukkan bahwa IHDI memperoleh skor 0.53 yang berada pada rentang 0.51-0.60 yang artinya penilaian IHDI adalah cukup baik.

Variabel ketiga yaitu kemandirian. Variabel kemandirian menggambarkan sejauh mana zakat dapat berdampak pada tingkat produktivitas dan menjadikan mustahiq mampu memenuhi kebutuhan hidupnya. Hasil penilaian variabel kemandirian mendapatkan skor 3 yang artinya rata-rata keluarga mustahiq memiliki salah satu pekerjaan tetap atau usaha/bisnis tidak semua memiliki tabungan sehingga mendapatkan nilai indeks 0.50 , artinya cukup baik.

\section{Indeks Zakat Nasional BAZNAS Kabupaten Solok}

Nilai Indeks Zakat Nasional BAZNAS Kabupaten Solok berdasarkan penghitungan tahap kelima, yaitu mengalikan indeks yang diperoleh pada setiap dimensi dengan bobot masing-masing disajikan pada tabel:

Tabel 1.6. Dimensi Makro Indeks Zakat Nasional BAZNAS Kabupaten Solok

\begin{tabular}{|c|c|c|l|c|c|}
\hline \multicolumn{1}{|c|}{ Variabel } & Skor & Indeks & \multicolumn{1}{|c|}{ Indikator } & Indeks & Dimensi \\
\hline- & - & - & Regulasi (X11) & 1,00 & \\
\hline- & - & - & $\begin{array}{l}\text { Dukungan APBD } \\
\text { (X12) }\end{array}$ & 0,00 & \\
\hline $\begin{array}{l}\text { Lembaga zakat resmi, } \\
\text { muzakki dan mustahiq } \\
\text { yang terdaftar (X131) }\end{array}$ & 3 & 0,50 & $\begin{array}{l}\text { Database lembaga } \\
\text { Zakat (X13) }\end{array}$ & 0,25 & Makro (X1)=0,50 \\
\hline $\begin{array}{l}\text { Rasio muzakki individu } \\
\text { (X132) }\end{array}$ & 2 & 0,25 & & & \\
\hline $\begin{array}{l}\text { Rasio muzakki badan } \\
\text { (X133) }\end{array}$ & 1 & 0,00 & & & \\
\hline
\end{tabular}

Berdasarkan tabel 1.6. ini menunjukkan bahwa indeks dimensi makro senilai 0,50. Perhitungan ini diperoleh dari nilai indeks masing-masing indikator. Nilai indeks 1,00. Hal ini dikarenakan pada BAZNAS Kabupaten Solok terdapat regulasi daerah mengenai pengelolaan zakat yang tertulis pada Peraturan Daerah Nomor 13 Tahun 2015 tentang Pengelolaan Zakat. Indikator dukungan APBD memperoleh nilai indeks 0,00 karena BAZNAS Kabupaten Solok tidak mendapatkan dukungan APBD sama sekali. Indikator database lembaga zakat memperoleh nilai indeks 0.025 yang artinya database lembaga zakat kurang baik. Hal ini dapat dilihat melalui variabel turunan pada database lembaga zakat, yaitu lembaga zakat resmi, jumlah muzakki dan mustahiq yang terdaftar, rasio muzakki individu, dan rasio muzakki badan usaha. Untuk variabel lembaga zakat resmi, jumlah muzakki, dan mustahiq yang 
terdaftar mendapatkan nilai indeks 0.50 karena BAZNAS Kabupaten Solok hanya memiliki database jumlah lembaga zakat resmi, jumlah muzakki, dan mustahiq tetapi tidak memiliki peta persebarannya. Hasil penelitian tidak sejalan dengan penelitian $\mathrm{Nadhia}^{30}$ yang melakukan penilaian kinerja BAZIS Jakarta Selatan. Pada penelitian tersebut menyatakan bahwa indikator regulasi mendapatkan nilai indeks 0.00 dikarenakan tidak terdapat regulasi mengenai pengelolaan zakat pada BAZIS Jakarta Selatan, sedangkan indikator APBD mendapatkan nilai indeks 1.00 dikarenakan BAZIS Jakarta Selatan mendapatkan dukungan APBD untuk menunjang operasional BAZIS Jakarta Selatan.

Variabel kedua, yaitu rasio muzakki individu mendapatkan nilai indeks 0.25. Hal ini didapatkan dari rasio jumlah muzakki terdaftar yang memiliki NPWZ terhadap rumah tangga muslim daerah adalah 1,44\%. Jumlah muzakki yang memiliki NPWZ di Kabupaten Solok sebanyak 5600 orang, sedangkan jumlah rumah tangga di Kabupaten Solok sebanyak 387.515 rumah tangga. Variabel ketiga, yaitu rasio muzakki badan usaha mendapatkan nilai indeks 0.00, artinya rasio muzakki badan usaha terhadap seluruh badan usaha di Kabupaten Solok sangat buruk. Rasio jumlah muzakki badan terdaftar yang memiliki NPWZ terhadap jumlah badan usaha adalah $0,72 \%$. Hasil penelitian ini tidak sejalan dengan penelitian yang dilakukan Hidayaneu $^{31}$ yang menyatakan bahwa hasil penilaian indikator database pada BAZNAS Bandung tidak baik dengan nilai indeks 0.00. BAZNAS Bandung tidak memiliki database muzakki dan mustahiq. Selain itu, rasio muzakki individu terhadap jumlah rumah tangga dan rasio muzakki badan usaha terhadapa jumlah badan usaha di daerah tersebut adalah rendah.

Setelah melakukan perhitungan pada dimensi makro, selanjutnya adalah perhitungan pada dimensi makro yang tercantum pada tabel berikut:

Tabel 1.7. Dimensi Mikro Indeks Zakat Nasional BAZNAS Kabupaten Solok

\begin{tabular}{|l|c|c|l|c|c|}
\hline \multicolumn{1}{|c|}{ Variabel } & Skor & Indeks & \multicolumn{1}{|c|}{ Indikator } & Indeks & Dimensi \\
\hline Penghimpunan (X211) & 4 & 0,75 & $\begin{array}{l}\text { Kelembagaan } \\
(\mathrm{X} 21)\end{array}$ & 0,70 & \\
\hline Pengelolaan (X212) & 3 & 0,50 & & & \\
\hline Penyaluran (X213) & 4 & 0,75 & & & Mikro(X2)=0,61 \\
\hline Pelaporan (X214) & 3 & 0,75 & & & \\
\hline $\begin{array}{l}\text { Indeks Kesejahteraan } \\
\text { CIBEST (X221) }\end{array}$ & 3 & 0,50 & $\begin{array}{l}\text { Dampak zakat } \\
\text { (X22) }\end{array}$ & 0,55 & \\
\hline $\begin{array}{l}\text { Indeks Pembangunan } \\
\text { Manusia Islami (X222) }\end{array}$ & 3 & 0,50 & & & \\
\hline Kemandirian (X223) & 3 & 0,50 & & & \\
\hline
\end{tabular}

Indeks dimensi mikro lebih besar dibandingkan makro dikarenakan nilai indeks dimensi mikro adalah 0,61. Dimensi mikro terdiri dari indikator kelembagaan dan dampak zakat. Indikator kelembagaan memiliki nilai indeks 0.70. Nilai ini didapatkan dari akumulasi perhitungan beberapa variabel. Variabel pertama, yaitu penghimpunan dengan nilai indeks 0.75. Perhitungan variabel pengumpulan terdiri dari jumlah pertumbuhan dana dan besaran

\footnotetext{
${ }^{30}$ Ibid.

${ }^{31}$ Ibid.
} 
pengumpulan. Pertumbuhan penghimpunan dana sebesar 22 persen yang artinya berada $>20 \%$ sehingga mendapatkan nilai indeks 1.00. Artinya, kinerja dari peningkatan penghimpunan baik, sementara dana yang dihimpun oleh BAZNAS Kabupaten Solok pada 2020 sebesar Rp. 8.700.000.000,- berada pada rentang 1 Milyar-10 Milyar mendapatkan nilai indeks 0.50 yang artinya cukup baik.

Variabel kedua, yaitu pengelolaan mendapatkan nilai indeks 0.50 yang artinya kinerja dalam pengelolaan cukup baik. Hal ini dapat dilihat melalui adanya program kerja tahunan, SOP penghimpunan dan penyaluran tetapi belum ada ISO/manajemen mutu dan rencana strategis yang dimiliki lembaga. Variabel ketiga, yaitu penyaluran mendapatkan nilai indeks sebesar 0.75 yang artinya penyaluran yang dilakukan dikatakan baik. Dana zakat yang dihimpun oleh BAZNAS Kabupaten Solok sesuai dengan jumlah penghimpunan. Variabel keempat, yaitu pelaporan. Nilai indeks pelaporan BAZNAS Kabupaten Solok adalah 0.75. Hal ini dikarenakan BAZNAS Kabupaten Solok memiliki laporan patuh terhadap syariah, selain itu laporan keuangan mendapatkan opini "wajar tanpa pengecualian" tetapi tidak dipublikasi.

Selain indikator kelembagaan dimensi mikro juga memiliki indikator dampak zakat. Indikator dampak zakat memiliki nilai indeks 0,50 yang disusun dari beberapa variabel. Variabel pertama, yaitu indeks kesejahteraan CIBEST dengan nilai indeks 0,47 yang artinya terdapat 47 rumah tangga mustahiq pada kuadran pertama yang memiliki kesejahteraan baik secara material maupun spiritual, terdapat 51 rumah tangga mustahiq pada kuadran kedua yang memiliki kekayaan spiritual tetapi miskin secara material, terdapat 2 rumah tangga mustahiq pada kuadran ketiga yang memiliki kekayaan material tetapi miskin secara spiritual, dan tidak ada rumah tangga mustahiq yang berada pada kuadran keempat atau miskin secara material dan spiritual.

Hasil penilaian indeks kesejahteraan CIBEST yang menghitung kondisi material dan spiritual mustahiq sebelum dan sesudah menerima zakat. Menunjukkan bahwa tidak terdapat perubahan nilai indeks material dan spiritual mustahiq, baik sebelum menerima zakat maupun sesudah menerima zakat. Hal ini dikarenakan pemberian zakat oleh BAZNAS Kabupaten Solok hanya dilakukan 1-2 kali dalam setahun. Pihak BAZNAS Kabupaten Solok hanya sekali saja mengunjungi rumah. BAZNAS Kabupaten Solok tidak melakukan pembinaan, monitoring dan evaluasi sehingga tidak terdapat dampak zakat dari sisi material dan spiritual mustahiq. Hasil penelitian ini sejalan dengan penelitian Nadhia $^{32}$ yang menyatakan bahwa dampak penyaluran zakat belum maksimal karena tidak terjadi perubahan yang signifikan

Pada variabel indeks pembangunan manusia islami, memiliki nilai indeks 0.50 . Penilaian ini dilakukan melalui perhitungan seluruh variabel yang terdiri dari indeks al-din yang meliputi jumlah masjid dan sekolah Islam dengan nilai indeks 0.41. Variabel kedua, yaitu indeks al-nafs yang meliputi angka harapan hidup dan angka kriminalitas dengan nilai indeks 0.41. Variabel ketiga, yaitu indeks $a l$ - 'aql yang meliputi angka melek huruf dan ratarata lama sekolah dengan nilai indeks 0.65. Variabel ketiga, yaitu indeks al-nasl yang meliputi angka kelahiran bayi, angka kematian bayi dan angka kematian ibu dengan nilai indeks 0.62. Dan yang terakhir yaitu indeks al-mal yang meliputi tingkat pendapatan

\footnotetext{
${ }^{32}$ Ibid.
} 
perkapitan, indeks gini dan kedalaman kemiskinan dengan nilai indeks 0.172. Nilai seluruh indeks dihitung menggunakan rumus indeks pembangunan manusia islami sehingga menghasilkan nilai indeks 0.53 yang artinya indeks pembangunan manusia islami Kabupaten Solok adalah cukup baik.

Variabel terakhir pada indikator dampak zakat adalah indeks kemandirian yang memiliki nilai indeks 0.50 yang artinya cukup baik, dikarenakan setiap mustahiq memiliki salah satu dari pekerjaan tetap atau usaha/bisnis dalam mencukupi kebutuhan hidupnya.

Hasil penilaian variabel IHDI dan kemandirian sejalan dengan penelitian dilakukan Hidayaneu $^{33}$ yang menyatakan bahwa penilaian variabel kemandirian mendapatkan nilai 0.50 atau cukup baik. Hal ini terjadi karena mayoritas responden memiliki pekerjaan atau usaha namun tidak memiliki tabungan.

Setelah nilai dimensi makro dan mikro didapatkan, selanjutnya adalah menghitung nilai indeks zakat nasional. Perhitungan indeks zakat nasional pada BAZNAS Kabupaten Solok adalah:

$$
\begin{aligned}
& \mathbf{I Z N}=\mathbf{0 . 3 0} \mathbf{X}_{\mathbf{1}}+\mathbf{0 . 7 0} \mathbf{X}_{\mathbf{2}} \\
& =0.30(0.50)+0.70(0.61) \\
& =0.577
\end{aligned}
$$

Berdasarkan penjabaran di atas maka dapat ditarik kesimpulan bahwa nilai indeks zakat nasional pada BAZNAS Kabupaten Solok adalah 0.577 yang artinya kinerja BAZNAS Kabupaten Solok secara keseluruhan adalah cukup baik. Hasil penelitian ini sejalan dengan penelitian Putri ${ }^{34}$ yang melakukan penelitian pada BAZNAS Kota Yogyakarta. Hasil IZN pada BAZNAS Kota Yogyakarta menunjukkan angka 0.4338 yang diperoleh dari akumulasi perhitungan setiap variable penyusun IZN. Nilai 0.4338 menjelaskan bahwa kinerja BAZNAS Kota Yogyakarta yang dijalankan sudah cukup baik. Selain itu, hasil penelitian ini juga sejalan dengan penelitian yang dilakukan oleh Khoirunnisa ${ }^{35}$ yang menunjukkan bahwa nilai IZN pada BAZNAS Kabupaten Cilacap adalah baik dengan nilai 0.52.

\section{Kesimpulan}

Berdasarkan analisis dan hasil pembahasan mengenai analisis model indeks zakat nasional untuk menilai kinerja zakat pada BAZNAS Kabupaten Solok, maka dapat diambil kesimpulan bahwa penilaian kinerja BAZNAS Kabupaten Solok berdasarkan dimensi makro adalah cukup baik dengan nilai indeks 0.50 . Indikator regulasi mendapatkan nilai sangat baik dikarenakan terdapat regulasi mengenai pengelolaan zakat, sedangkan indikator dukungan APBD untuk biaya operasional mendapatkan nilai indeks sangat tidak baik karena tidak terdapat dukungan APBD. Indikator databae mendapatkan nilai indeks kurang baik karena database lembaga zakat resmi, muzakki dan mustahiq yang terdaftar belum lengkap. Selain itu, rasio muzakki individu terhadap jumlah rumah tangga dan rasio muzakki badan usaha

\footnotetext{
${ }^{33}$ Ibid.

${ }^{34}$ Y. H. Putri, "Analisis Kinerja Pengelolaan Zakat di Badan Amil Zakat Nasional (BAZNAS) Kota Yogyakarta," Repository IPB (2017).

35 A. A. Khoirunnisa, "Analisis Kinerja Baznas Kabupaten Cilacap dengan Pendekatan Indeks Zakat Nasional," Repository IPB (2017).
} 
terhadap badan usaha yang ada di daerah kabupaten solok adalah rendah. Penilaian kinerja BAZNAS Kabupaten Solok berdasarkan dimensi mikro adalah baik dengan nilai indeks 0.61. Nilai indeks kelembagaan yang meliputi penghimpunan, penyaluran dan pelaporan sudah baik, tetapi nilai variabel pengelolaan cukup baik dikarenakan BAZNAS Kabupaten Solok belum memiliki ISO/Manajemen mutu dan rencana strategi. Selain itu, dampak zakat yang diberikan belum terlihat dikarenakan BAZNAS Kabupaten Solok belum melakukan pembinaan, monitoring dan evaluasi pada sisi material dan spiritual mustahiq.

\section{Daftar Rujukan}

Ahmed, H. "Zakah, Macroeconomic Policies, and Poverty Alleviation: Lessons from Simulations on Bangladesh," Journal of Islamic Economics, Banking and Finance, Volume 4, Nomor 2 (2008).

al-Zuhayli, Wahbah. Zakat: Kajian Berbagai Mazhab. Jakarta: PT. Remaja Rosdakarya, 2002.

Atabik, A. "Peranan Zakat dalam Pengentasan Kemiskinan," ZISWAF, Volume 2, Nomor 2 (Desember 2015).

Badan Amil Zakat Nasional. Indeks Zakat Nasional 2.0. Jakarta: Pusat Kajian Strategis BAZNAS, 2020.

Badan Amil Zakat Nasional. Zakat Core Principles. Jakarta: Badan Amil Zakat Nasional, 2016.

Badan Pusat Statistik. Garis Kemiskinan Menurut Kabupaten/Kota di Sumatera Barat (rupiah/kapita/bulan) 2018-2020. Padang: Badan Pusat Statistik Sumatera Barat, 2020.

Bank Indonesia. Pengelolaan Zakat yang Efektif: Konsep dan Praktik di Beberapa Negara. Jakarta: Departemen Ekonomi dan Keuangan Syariah Bank Indonesia, 2016.

BAZNAS Kabupaten Solok. "Potensi Zakat Kabupaten Solok" dalam Laporan BAZNAS Kabupaten Solok tahun 2019.

Daulah, M. A. "Efektifitas Pengelolaan Perda Pengelolaan Zakat di Kota Mojokerto dan Kabupaten Sidoarjo," Jurnal Hukum dan Perundangan Islam, Volume 3, Nomor 2 (2015).

Direktorat Pemberdayaan Zakat Depag RI. Pedoman Pengelolaan Zakat. Jakarta: Direktorat Bimbingan Masyarakat Islam, 2007.

Farchatunnisa, H. “Analisis Kinerja Baznas Kota Bandung dengan Pendekatan Indeks Zakat Nasional," Repository IPB (2017).

Hafidhuddin, D. Zakat dalam Perekonomian Modern. Jakarta: Gema Insani, 2002.

Hasan, M. A. Zakat dan Infak. Jakarta: Prenada Media Group, 2006.

Ibn Shalih, Muhammad. Fatwa-Fatwa Zakat. Jakarta: Darus Sunnah Press, 2008.

Kementerian Agama RI. "Jumlah Penduduk Menurut Kabupaten/Kota dan Agama yang Dianut”. Dalam rupawan.kemenag.go.id. Diakses pada 11 Agustus 2020.

Khoirunnisa, A. A. "Analisis Kinerja Baznas Kabupaten Cilacap dengan Pendekatan Indeks Zakat Nasional," Repository IPB (2017).

Mukhlis, Ahamd. "Analisis Faktor-Faktor yang Mempengaruhi Tingkat Kepatuhan Membayar Zakat: Studi Kasus Kabupaten Bogor," Al-Muzara'ah, Volume 1, Nomor 1 (2019). 
Noor, A. H. "Assessing Performance of Nonprofit Organization: A Framework for Zakat Institutions," British Journal of Economics, Finance and Management Sciences, Volume 5, Nomor 13 (2012).

Putri, Y. H. "Analisis Kinerja Pengelolaan Zakat di Badan Amil Zakat Nasional (BAZNAS) Kota Yogyakarta," Repository IPB (2017).

Rahman, S. R. “Assesment of Zakat Distribution," International Journal of Islamic and Middle Eastern Finance and management: Emerald Insight, Volume 12, Nomor 5 (2019).

Rukiah, A. N. "Islamic Human Development Index di Indonesia (Suatu Pendekatan Maqhasid Syariah)," Istinbath, Volume 4, Nomor 2 (2019).

Shalehanti, Nadhia. “Analisis Kinerja BAZIS Jakarta Selatan,” Repository IPB (2017).

Sugiyono. Metode Penelitian Kuantitatif, Kualitatif dan R\&D. Bandung: Alfabeta, 2013. www.bps.go.id diakses pada 12 Agustus 2020. 